I. RÉSZ

A FOGYASZTÓI ADÁSVÉTEL EGYES KÉRDÉSEINEK SZABÁLYOZÁSA ÉS JOGGYAKORLATA 



\title{
A FOGYASZTÓI ADÁSVÉTEL EGYES KÉRDÉSEINEK SZABÁlYOZÁSA ÉS JOGGYAKORLATA CSEHORSZÁGBAN ${ }^{\mathrm{I}}$
}

\author{
JiŘí HRÁdeK
}

Debreceni Jogi Mühely, 2020. ÉVi (XVII. évfolyam) I-2. DOI I $0.24 \mathrm{I} 69 / \mathrm{DJM} / 2020 / \mathrm{I}-2 / \mathrm{I}$

\section{A szabályozás kialakulása és hatályos állapota}

A fogyasztási cikkek adásvételének és a kapcsolódó jótállásnak egyes vonatkozásairól szóló, 1999. május 25-i 1999/44/EK európai parlamenti és tanácsi irányelvet ${ }^{2}$ (továbbiakban: 1999/44/EK irányelv) a cseh jogalkotó a 2012. évi 89. számú Polgári Törvénykönyvben (továbbiakban: CsPtk.)³ a fogyasztókkal kötött adásvételi szerződések keretei között ültette át a nemzeti jogba. A részletes szabályokat a CsPtk. 4. rész II. főfejezetének 5. alszakasza - „A fogyasztási cikkek adásvételére vonatkozó különös rendelkezések" - tartalmazza (CsPtk. 2158-2174.\$-ai). Ezen szabályok azonban önmagukban nem elég komplexek, ezért a CsPtk. általános rendelkezéseit is alkalmazni kell. Következésképpen az adásvételi szerződések általános szabályait, azon belül pedig az ingók és ingatlanok adásvételének különös szabályait, valamint a hibás teljesítésért való felelősség általános szabályait kell alkalmazni a fogyasztókkal kötött adásvételi szerződésre (CsPtk. 1916-1925. \$-ai).

Ezen túlmenően a fogyasztókkal kötött adásvételi szerződés néhány aspektusát az 1992. évi 634. számú fogyasztóvédelemről szóló törvény (a továbbiakban: CsFvt.) is szabályozza, amely számos fogyasztói jogot definiál, így például a konkretizálja a hibás teljesítésből származó jogok gyakorlásának módját (reklamáció, panaszkezelés).

A vonatkozó cseh jogszabályok személyi hatálya nemcsak a fogyasztókra vonatkozik, hanem más olyan személyre is kiterjed, akik nem üzleti tevékenységükhöz tartozó célból járnak el [CsPtk. 2158. \$ (1) bekezdése]. Ezt a szempontot a korábbi Polgári Törvénykönyv (1964. évi 40 sz. törvény) alakította

1 A tanulmány megírása és megjelentetése az Igazságügyi Minisztérium jogászképzés színvonalának emelését célzó programjai keretében valósult meg.

2 Az Európai Parlament és a Tanács 1999/44/EK irányelve (1999. május 25.) a fogyasztási cikkek adásvételének és a kapcsolódó jótállásnak egyes vonatkozásairól, HL L 171., 1999.7.7., 12-16.

3 Zákon č. 89/2012 Sb., občanský zákoník. (2012. évi 89. számú Polgári törvénykönyv) 
ki, azzal indokolva, hogy a vásárló gyengébb szerződő félnek minősül. Noha az 2014-es új CsPtk. szabályait progresszívnek kell minősítenünk, az 1999/44/EK irányelv átültetése nem tekinthető hibátlannak és sok esetben nem is következetes. Mindezeket az egyes fejezeteknél külön is bemutatjuk, ugyanakkor néhány alapvető jogelméleti és a gyakorlati problémát meg kell említenünk elöljáróban is, mivel a joggyakorlat sem kezeli öket egységesen:

- A leggyakrabban vitatott kérdés a kellékhibákért való felelősség és az úgynevezett törvényes jótállás viszonya, amelyet a régi 1964. évi 40. számú Polgári Törvénykönyv szabályozott. A hatályos új CsPtk. szövege nem egyértelmű ebben a kérdésben, csak az átvételkor fennálló hibákkal kapcsolatos felelősséget említ [CsPtk. 2161.\$(1) bekezdése], nem pedig az átvétel után keletkezett hibákat.

- Problémát jelent továbbá a hibás teljesítésből fakadó jogok hierarchiája, amely - az általános és a különös szabályok együttélése miatt - zavaró és félrevezető.

- Nincs bizonyosság a fogyasztókkal kötött adásvételi szerződés tárgyi hatálya tekintetében sem. Ebben az összefüggésben a törvény az „áruk” kifejezést használja az 1999/44/EK irányelvvel összhangban, tehát az irányelvben foglalt szabályok természetéből fakadóan elsősorban ingó dolgokat kell értenünk ezalatt. Ugyanakkor a „tárgy” általános jogi kifejezést is használja a törvény, amely ingatlan- és ingó dolgokat egyaránt magába foglal. Következésképpen az uralkodó jogtudományi álláspont az, hogy a fogyasztókkal kötött adásvételi szerződések cseh szabályozása ingatlanokra is vonatkozik.

- A jelenlegi jogszabályok nem veszik kellőképpen figyelembe az 1999/44/EK irányelv 4. és 6. cikkét, amelyek a végsőeladó visszkereseti igényét szabályozzák a szerződésláncban korábban álló a felelös személlyel (személyekkel) szemben, valamint a jótállás feltételeit. ${ }^{4}$

Ezek a problémák jelenleg a jogalkotó asztalán vannak, ugyanis módosítani tervezik a CsPtk.-t. A módosító novella egyrészt igyekszik pótolni ezeket a hiányosságokat, de arra is hivatott, hogy átültesse a digitális tartalom szolgáltatására és digitális szolgáltatások nyújtására irányuló szerződések egyes

4 ACsPtk.módosításánaktervezete,1170/19.sz.,elérhető:https:/lapps.odok.cz/veklep-detail?'pid=KORNBFQGCDCT (letöltés dátuma: 2020.02.10.) 
vonatkozásairól szóló (EU) 2019/770 irányelvet, ${ }^{5}$ valamint az áruk adásvételére irányuló szerződések egyes vonatkozásairól szóló (EU) 2019/771 irányelvet. ${ }^{6}$ A módosítások kidolgozása egyelőre folyamatban van, ezért a tervezetre csak részben térünk ki.

Fontos megjegyzést kell füznünk az alkalmazott terminológiára nézve: Az 1999/44/EK irányelv által meghatározott és alapvető fogalomként alkalmazott a „szerződésnek való megfelelés hibája” helyett a cseh jogszabályok a „vada” (hiba) kifejezést használják. Ugyanakkor ugyanazt a „vada” (hiba) kifejezést használják a hibás termékekért való felelősségre vonatkozó tagállami törvényi, rendeleti és közigazgatási rendelkezések közelítéséről szóló 85/374/EGK irányelv (termékfelelősségi irányelv) ${ }^{7}$ kapcsán is, amit a CsPtk. 2939. \$-a ültetett át. ${ }^{8}$ A CsPtk. mindkét fogalmat külön-külön definiálja, azonban mégis ugyanazt a „hiba” kifejezést használja mindkét fogalom esetén, ami igen zavaró, ezért a jogalkalmazónak különösen tisztába kell lennie a fogalmi eltérésekkel, amikor alkalmazza a „szerződésnek való megfelelés hibája” vagy a „termékfelelősségi hiba” fogalmát. Az egységes cseh terminológia miatt a szerzők itt is a "hiba” kifejezést fogják használni, a szerződésnek való megfelelés hibája esetén is.

\section{A fogyasztó fogalma a cseh jogban}

A fogyasztó fogalmát a CsPtk. 419. \$-a adja meg, amelynek értelmében: fogyasztó az a természetes személy, aki üzleti tevékenységén vagy önálló szakmája gyakorlásán kívül köt szerződést egy vállalkozással; vagy azzal egyéb módon üzletet köt. E rendelkezés értelmében csak természetes személy lehet fogyasztó. A fogyasztó közigazgatási jogi meghatározását a CsFvt. tartalmazza, amelynek értelmében a fogyasztót „természetes személynek kell tekinteni, aki üzleti vagy szakmai tevékenységén kívül jár el”. A fogyasztókkal kötött adásvételi szerződés alkalmazása során csupán a magánjogi meghatározásból kell kiindulnunk.

5 Az Európai Parlament és a Tanács (EU) 2019/770 irányelve (2019. május 20.) a digitális tartalom szolgáltatására és digitális szolgáltatások nyújtására irányuló szerződések egyes vonatkozásairól, HL L 136., 2019.5.22., 1-27.

6 Az Európai Parlament és a Tanács (EU) 2019/771 irányelve (2019. május 20.) az áruk adásvételére irányuló szerződések egyes vonatkozásairól, az (EU) 2017/2394 rendelet és a 2009/22/EK irányelv módosításáról, valamint az 1999/44/EK irányelv hatályon kívül helyezéséről, HL L 136., 2019.5.22., 28-50.

7 A Tanács irányelve (1985. július 25.) a hibás termékekért való felelősségre vonatkozó tagállami törvényi, rendeleti és közigazgatási rendelkezések közelítéséről, HL L 210., 1985.8.7., 29-33.

8 A (nem megfelelő) átültetésről lásd: J. Hrádek: Damage caused by Product Defects and (Legitimate) Expectation Concerning Product Safety. In: V.L. Petrov, V. Tokušev (eds.): Sbornik naučni izsledovanie v pamet na doc. Christian Takov. Universitetsko izdatelstvo „Sv. Kliment Ochridski“, Sofia, 2019, 312-324. 
Az Európai Unió Bírósága gyakorlatának megfelelően - különös tekintettel a C-269/95 vagy a C-497/13 ${ }^{10}$ esetekre - a cseh jog követi azt a koncepciót, hogy a fogyasztó fogalmát szűken és mindig az adott szerződéssel összefüggésben kell értelmezni; különös tekintettel annak jellegére és céljára, mivel a vevő magatartása meghatározó lehet jogi helyzete szempontjából. Ugyanazt a személyt fogyasztónak és vállalkozónak is lehet tekinteni, attól függően, hogy milyen árut vásárol, és milyen célra használja fel azt. A vállalkozások és a fogyasztók minősítését a résztvevők akaratától függetlenül, objektív kritériumok alapján kell meghatározni, így nem a szerződő felek szempontjai, hanem cselekedeteik objektív minősítése a döntő. A fogyasztókkal kötött adásvételi szerződés speciális rendelkezéseinek eredményeképpen (CsPtk. 2158. és azt követő \$-ok) a vevő nem minden esetben lesz fogyasztó. Társaság, alapítvány, társulás vagy betétesek társulása is lehet vevő, ha nem üzleti tevékenysége során köti meg a szerződést. Ez a következtetés abból a tényből fakad, hogy a törvény nem korlátozza az adott típusú szerződést a fogyasztó és a vállalkozás kapcsolatára. Minden olyan szerződéses kapcsolatra vonatkozik, ahol az egyik fél üzleti tevékenysége keretében köti a szerződés, míg a másik fél azon kívül. A „fogyasztói adásvételi szerződés” kifejezést csak nem hivatalosan használják, a törvény az „Áruk üzleti célú értékesítésére vonatkozó különös rendelkezések” kifejezést használja.

\section{A szerződésszerúség vizsgálata a nemzeti jogszabályokban és az ítélkezési gyakorlatban}

A szerződésszerűség hiányát (a hibás teljesítést) a CsPtk. 2161.\$-a rendezi, amely meghatározza az áruk minőségi feltételeit a „átvételkori minőség” (jakost pri prevzeti) megnevezés alatt. A „hiba” a meghatározott követelményektől való eltérést jelenti. Terminológiai szempontból az áruk minőségére vonatkozó fenti hivatkozás pontatlan, mivel a minőségi követelményeken kívül a CsPtk. 2161. \$-a számos egyéb paramétert is tartalmaz, amelyekkel rendelkeznie kell az árunak. ${ }^{11}$ Ennélfogva helyénvaló, hogy úgy alkalmazzuk a rendelkezés szövegét, hogy az áruknak hibátlannak és így „tökéletesnek” kell lenniük. A tökéletesség

9 C-269/95. sz. Benincasa kontra Dentalkit ügyben 1997. július 3-án hozott ítélet (ECLI:EU:C:1997:337)

10 C-497/13. sz. Froukje Faber kontra Autobedrijf Hazet Ochten BV ügyben 2015. június 4-én hozott ítélet (ECLI:EU:C:2015:357)

11 L. Tichý, \$2161. In J. Švestka, J. Dvořák, J. Fiala et al. (eds.): Občanský zákoník, komentár. Sv. V., Wolters Kluwer, Prague, 2014, 960. 
mindig a felek megállapodásától vagy a jogszabály rendelkezésétől függ, ha abból az áru szükséges tulajdonságai vezethetők le.

A CsPtk. 2161. \$-a következő követelményeket írja elő az áru tulajdonságaira és egyéb paramétereire nézve, amelyekkel az árunak már az átvétel időpontjában rendelkeznie kell:

a) az áru (tárgy) rendelkezik a felek által megállapított tulajdonságokkal, és külön megállapodás hiányában az eladó vagy a gyártó által leírtakkal vagy a vevő által elvárt tulajdonságokkal, figyelemmel az áruk jellegére és azok reklámjára;

b) az áru alkalmas az eladó által meghatározott célra, vagy amelyre általában egy ilyen árut használnak;

c) az áru megfelel a szerződés szerinti mintának vagy modellnek a minőség vagy a kivitelezés szempontjából, feltéve, hogy a minőséget vagy a kivitelezést a megállapodás szerinti minta vagy modell alapján határozták meg;

d) az árut megfelelő mennyiségben, méretben vagy súlyban teljesítették; és

e) az áru megfelel a jogszabályban meghatározott követelményeknek.

A CsPtk. 2099. \$-a alapján a szükséges dokumentumok hiányosságait is hibának kell tekinteni az adásvételi szerződések általános szabályai értelmében. Ha az előírt tulajdonságok bármelyike hiányzik, akkor az áru hibásnak minősül. Hibának kell tekinteni az összeszerelési hiányosságokat is, mert az áru összeszerelése szerves részét képezi az eladó adásvételi szerződésből eredő kötelezettségeinek. ${ }^{12}$

Az 1999/44/EK irányelv 5. cikkének (3) bekezdéséhez képest (hibás teljesítés jogi vélelme) a cseh jogalkotó nagyvonalúbb volt a cseh fogyasztóval. A CsPtk. 2161. $\$(2)$ bekezdése szerint, ha a hiba az átvételt követő hat hónapon belül jelentkezik, akkor az árut már az átvétel időpontjában hibásnak kell tekinteni. Ezért a vevőnek nem kell bizonyítani, hogy a hiba már az átvétel pillanatában fennállt, csupán azt, hogy az áru nem felel meg a szerződésben vagy jogszabályban foglaltaknak. Ezenkívül a „szerződésszerűség hiánya” (hibás teljesítés) is jogi vélelmen alapul. ${ }^{13}$ Ami a védekezést illeti, az eladónak a vélelmet

12 P. Hubková: \$2161. In: J. Petrov, M. Výtisk, V. Beran et al. (eds.): Občanský zákoník, komentár̆. C.H.BECK, Prague, 2017, 2185.

13 L. Tichý: \$2161. i. m., 963. 
teljes mértékben meg kell döntenie, a hiba okainak megkérdőjelezése nem elegendő bizonyíték.

A szerződésszerűség szempontjából meg kell említenünk, hogy a fogyasztókkal kötött adásvételi szerződés keretében a CsPtk. 2158. \$-ának értelmében vett „dolog” fogalma (CsPtk. 489. \$) a jogi értelemben vett tárgyra is vonatkozik. Mivel a CsPtk. nem határozza meg a fogyasztói szerződések alapján értékesített termék jellegét, és nem szükíti annak funkcionális koncepcióját, az áruk mind ingók, mind ingatlanok is lehetnek. A jótállási szabályok ingatlanokra vonatkozó alkalmazásának feltétele csupán az, hogy a kérdéses szerződést az üzletszerű ingatlan kereskedelmet folytató személlyel, vállalkozóval kösse meg a „fogyasztó”. ${ }^{14}$

\section{A szavatossági és jótállási igények érvényesítésének szabályai}

A hibás teljesítésért való felelősségre vonatkozó szabályokat, illetve az igényérvényesítés (igények közötti választás) általános feltételeit a CsPtk. 1923. \$-a tartalmazza, továbbá az adásvételi szerződésre vonatkozó különös rendelkezéseket is alkalmazni kell (CsPtk. 2106. \$). Ezek a szabályok azonban nem kifejezetten vonatkoznak a fogyasztási cikkek adásvételére, mivel a hibás teljesítésből eredő jogokat átfogóan szabályozzák. De a károk egyidejű megtérítésének a CsPtk. 1925. \$-ában előírt lehetősége, azaz a hibás teljesítésből eredő jogok érvényesítése és a kártérítési szabályok párhuzamos alkalmazása, valamint a költségek megtérítésének lehetősége is CsPtk. 1924. \$-a szerint alkalmazandó.

A CsPtk. 2169. \$-a tartalmazza a hibás teljesítésből eredő jogok szabályait. Ezen jogokat három alapvető kategóriába lehet sorolni: (i) kiegészítő teljesítéshez való jog; (ii). elállási jog; és (iii) árleszállításhoz való jog. ${ }^{15}$

14 P. Hubková: \$2158. In: J. Petrov, M. Výtisk, V. Beran et al. (eds.): Občanskýzákoník, komentár. C.H.BECK, Prague, 2017, 2182.; L. Tichý: $\$ 2114$. In J. Švestka, J. Dvořák, J. Fiala et al. (eds.): Občanský zákoník, komentár. Sv.V., Wolters Kluwer, Prague, 2014, 848. lásd például a Legfelsőbb Bíróság 33 Odo 1314/2005. és33 Cdo 2889/2015. számú határozatait.

15 A CsPtk. 2169. \$-a értelmében: a vevő a hibátlan új árucikk átadását is kérheti, kivéve, ha ez a hiba jellege miatt észszerűtlen. Ha ez nem lehetséges, a vevő elállhat a szerződéstől. Ha azonban ez [t. i. az elállás] a hiba jellege miatt aránytalan, különösen, ha a hiba indokolatlan késedelem nélkül helyreállítható, a vevőnek joga van a hiba térítésmentes helyreállításához. (2) A vevőnek helyreállítható hiba esetén is joga van arra, hogy új árucikk átadását vagy egy alkatrész cseréjét kérje, ha az árucikk nem használható rendesen a hiba javítás utáni ismételt előfordulása miatt, vagy nagyobb számú hiba esetén. Ebben az esetben a vevőnek jogában áll elállni a szerződéstől. (3) Ha a vevő nem áll el a szerződéstől vagy nem él az új hibátlan termék átadásának, az alkatrész cseréjének vagy a termék javításának lehetőségével, akkor észszerủ árengedményre jogosult. A vevő jogosult észszerü árengedményre akkor is, ha az eladó nem tudja új hibátlan termék átadását, az alkatrészét kicserélését vagy a termék megjavítását vállalni; vagy ha az eladó észszerű időn belül nem javítja meg a terméket; vagy ha a javítás jelentős nehézségeket okozna a vevő számára. 
Az alapvető különbség az adásvételi szerződés hibás teljesítéséért való felelősség általános szabályaihoz képest az, hogy a CsPtk. 2106. \$ (1) bekezdésétől eltérően a 2169. \$-rendelkezése nem engedélyezi a hibás teljesítés esetén a pótlólagos teljesítést. A CsPtk. 2169. \$-a szerinti kiegészítő teljesítéshez való jog tehát csupán abban az esetben eredményezheti a dolog kijavítását, ha a dolog egy részének pótlása szükséges; a föszabály az, hogy a vevő új termékre történő kicserélést kérhet. Mindazonáltal úgy gondoljuk, hogy a rendelkezés általános jellegénél fogva az eladó kiegészítheti a hibás teljesítést.

Ami az egyéni jogorvoslati lehetőségeket illeti, a dolog cseréjéhez való jog a dolog konkrét jellegétől függ, azaz igazodik annak értékéhez és az alkatrészrész cseréjének vagy javításának költségeihez. A csere kizárólag ugyanolyan dologra történő kicserélést jelent (szín, típus stb.), ugyanakkor a törvény nem zárja ki azt sem, hogy az eladó jobb minőségű termékre cserélje ki az eredeti terméket. Ha azonban a kicserélt termék jobb minőségű, az eladó nem jogosult megfizettetni az árkülönbözetet a fogyasztóval. Ha a hiba csupán a dolog egy részét érinti, akkor a csere jogát csak az adott részre gyakorolhatja a fogyasztó.

Ha a fenti esetekben nincs lehetőség cserére, a fogyasztó javítást igényelhet. Ha azonban a javítás ellenére ismét bekövetkezik a hiba, amely az ítélkezési gyakorlat szerint akkor fordul elő, ha az eladó kétszer is megkísérelte kijavítani a hibát, de az ennek ellenére ismét bekövetkezik, akkor a vevő kérheti a dolog kicserélését. ${ }^{16}$

Az elállási jog csak akkor gyakorolható, ha az árut vagy annak részét nem lehet kijavítani vagy kicserélni, vagy ha a hibák ismételten megjelennek, vagy a terméknek több (háromnál több) hibája van. Ha a vevő gyakorolja az elállási jogot, akkor a szerződést ab initio megszüntetik, így a vevő köteles visszaadni a hibás terméket az eladónak. Az eladó viseli a visszaküldés költségeit, és ha a vevő a terméket rendeltetésszerüen és a jóhiszemüség és tisztesség követelményének megfelelően használta, akkor nem lesz köteles megtéríteni az jogalap nélküli gazdagodást az eladónak a teljesítésig visszamenően. ${ }^{17}$ Másrészről azonban a vevőnek joga van visszaszolgáltatni az eladónak a szerződés teljesítéseként nyújtott dolgot az elállás időpontjában.

16 A Legfelsőbb Bíróság 33 Cdo 1323/2013. számú határozata.

17 A Legfelsőbb Bíróság 30 Cdo 68/2007. számú határozata. 
A vevő ezen túl választhatja az árleszállítás jogát is, ha semmiféle egyéb igényt nem nyújt be, vagy az eladó nem teljesíti az érvényesíteni kívánt igényeket. Így az árleszállításhoz való jog nem minősül másodlagos vagy harmadlagos követelésnek, hanem a vevő különálló elsődleges jogaként funkcionál a hibás teljesítésért való felelősség szabályai között. ${ }^{18}$

A vevőnek joga van arra, hogy válasszon a szavatossági jogok közül, de a szavatossági jogok nem azonos szinteken helyezkednek el és ezek érvényesítése során az eladó képességeit, kompetenciáját is figyelembe kell venni. Így a szavatossági jogok közötti választás során a vevő joga meglehetősen korlátozott az eladóval szemben. Ezt a szempontot az eset összes körülményeit figyelembe véve objektívnek kell tekinteni. Ugyanakkor a fogyasztó szempontjai tekinthetők döntőnek, amelyet például a „amennyiben az nem jelent jelentős nehézséget a fogyasztó számára” megállapítások fejeznek ki. ${ }^{19}$

\section{A szavatossági és jótállási igények érvényesítésének határidői}

A hibás teljesítésből eredő jogok gyakorlására vonatkozó határidőt a CsPtk. 2165. \$ a következőképpen szabályozza: (i) a vevő a fogyasztási cikkek hibás teljesítéséből származó jogait az átvételtől számított 24 hónapon belül gyakorolhatja és (ii) ha az az áru csomagolásán, vagy az ahhoz mellékelt leírásban vagy a reklámban más jogi szabályozással összhangban - feltüntetik az áru használhatóságának idejét, akkor a minőségi jótállásra vonatkozó szabályokat kell alkalmazni.

\subsection{A szavatossági határidők}

A CsPtk. tehát kétféle esetet határoz meg. Az első a vásárlónak a hibás teljesítésből származó jogainak gyakorlására vonatkozó feltételeket szabályozza, azaz a dolog átadás napján fennálló hibáiért való felelősség kérdéseit; a második tényállás a jótállást szabályozza (CsPtk. 2113. \$), amelyet azáltalános felelősségi szabályoknak rendel alá.

A hibás teljesítésért való felelősség esetén a jogalkotó csak azt írja elő, hogy a vevő az áru kézhezvételétől számított két éven belül köteles a hibás teljesítésből eredő jogait érvényesíteni az eladóval szemben (CsPtk. 2172. \$).

18 L. Tichý: \$2169. In J. Švestka, J. Dvořák, J. Fiala et al. (eds.): Občanský zákonik, komentářr. Sv. V., Wolters Kluwer, Prague, 2014, 983.

19 L. Tichý: \$2169. i. m., 980. 
$\mathrm{Ez}$ az időintervallum tulajdonképpen meghatározza azt az időszakot, amelyen belül a hibának meg kell mutatkoznia. ${ }^{20} \mathrm{~A}$ jogalkotó azonban kifejezetten nem határoz meg más határidőket, így azt sem, hogy a hiba megjelenése után milyen határidőn belül kell értesítenie a vevőnek az eladót a hibákról. Ez alapvető különbség a kontraktuális felelősségre vonatkozó általános szabályozáshoz képest, ugyanis arra vonatkozólag a CsPtk. 2112. \$-a konkrétan előírja, hogy a vevőnek indokolatlan késedelem nélkül kell értesítenie az eladót a hibáról, miután a vevő megvizsgálta és elegendő gondossággal beazonosította a hibát; valamint rejtett hiba esetén, indokolatlan késedelem nélkül, miután a vevő elegendő gondossággal észlelni tudta a hibát. Miután a CsPtk. 2165. \$-a különös szabályt állapít meg, ezért a CsPtk. 2112. \$-ában található általános szabályok nem alkalmazhatók a fogyasztókkal kötött adásvételi szerződésekre.

A CsPtk. 2168. \$-a semmisnek nyilvánítja a jogérvényesítési határidők bármilyen korlátozását, akkor is, ha arról az eladó és a vevő állapodik meg. Ez a tilalom azonban nem alkalmazható használt fogyasztási cikkek esetében, amennyiben a korlátozás nem haladja meg a törvényes határidő felét. Ha a felek a megengedettnél rövidebb határidőben állapodnak meg, akkor a jogszabályban előírt időszak felét, azaz 12 hónapot kell irányadónak tekinteni. Ezt a határidőt a használt fogyasztási cikkek minimális szavatossági határidejének kell tekintenünk.

Tichý szerint annak ellenére, hogy a CsPtk. 2165. \$-a nem ír elő konkrét határidőt a hibák eladó részére történő bejelentésére a hiba észlelését követően, a jóhiszeműség és tisztesség elvének figyelembevételével, a fogyasztónak indokolatlan késedelem nélkül kell értesítenie az eladót, mivel egyébként a késlelkedést contra bonos mores-nek ${ }^{21}$ kell tekintenünk. Ezen következtetés helytállóságát a CsPtk. 2165. §-ára vonatkozó módosítástervezet is alátámasztja, amely konkretizálja az értesítési határidőt az „indokolatlan késedelem nélküli értesítés határideje”-ként definiálva (ugyanakkor tükrözi az 1999/44/EK irányelv vonatkozó rendelkezését, amely értelmében ez az időtartam nem lehet rövidebb, mint 2 hónap). A tervezet szerint: „A bíróság akkor is megadja a hiba érvényesítésének jogát, ha a hibát nem érvényesítették indokolatlan késedelem nélkül azután, hogy a vevő kellő gondossággal észlelhette a hibát." 22

20 M. Hulmák: Prostředky právní ochrany kupujícího při spotřebitelské koupi. In: L. Tichý, M. Kocí (ed.): Spotrebitelská kupni smlouva Centrum právní komparatistiky, Praha, 2013 38-39.

21 L. Tichý: \$2165. In J. Švestka, J. Dvořák, J. Fiala et al. (eds.): Občanský zákoník, komentár. Sv. V., Wolters Kluwer, Prague, 2014, 971.

22 A CsPtk. módosításának tervezete, i. m. 
A 24 hónapos jótállási időszakra vonatkozóan más vélemény is létezik a jogirodalomban, amely elsősorban a jogszabályok folytonosságán alapul, a 24 hónapos, úgynevezett törvényes jótállást a régi CsPtk. vezette be. Ezen vélemény képviselői szerint ${ }^{23}$ a 24 hónapos időszak nem a hibás teljesítésből származó igények érvényesítésének határidejét jelenti az eladóval szemben, hanem azt az időszakot jelöli meg, amely idő alatt az eladó felel a hibákért. Ezt a nézetet nem tartjuk helyesnek, mivel egy ilyen következtetés a hatályos CsPtk. terminológiájának és szisztematikájának sem nem felel meg. Más oldalról közelítve ugyanakkor a kérdéses törvényi norma nyelvtani értelmezéséből kiindulva helyesnek kellene ítélnünk ezt az érvelést. ${ }^{24}$

\subsection{A jótállás tartalma}

Ami a jótállás tartalmát és az arra vonatkozó közérthető információkat illeti, az 1999/44/EK irányelv 6. cikkében megállapított feltételek hiányoznak a cseh jogból. A jótállásból eredő fogyasztói jogokat sem a CsPtk. 2165. \$-a, sem a 2113 . \$-a nem határozzák meg részletesen. Ezért kérdéses, hogy a jogalkotó szándékosan hagyta-e ki a jótállás tartalmi elemeit a törvényből, vagy az eladót kötelezi-e a szóban forgó irányelvi cikk és elvárható-e tőle, hogy eurokonform interpretációnak megfelelően alkalmazza a CsPtk. 2113. \$-át és részletesen informálja a fogyasztót a jótállás tartalmáról? ${ }^{25}$ Mivel a jótállás nem érinti a hibás teljesítéshez füződő jogokat, feltételezhetjük, hogy a jótállási idő megegyezik az áru használati időtartamával, és a fogyasztó jogok korlátozása az eladón múlik. Amennyiben az eladó nem korlátozza a fogyasztó jogait, akkor a fogyasztó a jótállási idő teljes időtartama alatt érvényesítheti jogait.

\subsection{A fogyasztó jogainak korlátozása}

A CsPtk. 2167. \$-a értelmében a vevő nem rendelkezik kötelező szavatossági vagy jótállási joggal abban az esetben, ha a vásárlás időpontjában tudomást szerzett a hibáról vagy a hibát maga okozta. A törvény a következő esetekben zárja ki a fogyasztó hibás teljesítésből eredő jogainak érvényesítését:

23 P. Hubková: \$2165. In: J. Petrov, M. Výtisk, V. Beran et al. (eds.): Občanský zákoník, komentár. C.H.BECK, Prague, 2017, 2189.; B. Vítová: \$2165. In: M. Hulmák et al. (eds.): Občanský zákoník VI. Závazkové právo. Zvlástni cást (\$ 2055-3014). C.H.Beck, Prague, 2014, 158.

24 LásdB. Vítová: $\$ 2165$. i. m., 159.

25 L. Tichý: \$2165. i. m., 972. 
a) ha a felek a dolog hibájának ismeretében alacsonyabb vételárban állapodtak meg;

b) a dolog szokásos mértékű használatából vagy hordásból származó hibáiért;

c) használt áruk olyan hibáiért, amely a használtság vagy hordás mértékével megegyezik, és a vevő átvette az árut;

d) a tárgy jellegéből adódó hibák esetében.

Ez a rendelkezés azonban nem kötelező, és nem zárható ki az sem, hogy az eladó több jogosultságot biztosítson a vevőnek, mint amit a törvény elöír. ${ }^{26}$

\subsection{A hibás teljesítés által okozott költségek viselése}

A jogok érvényesítésével kapcsolatos költségek sorsát a CsPtk. 1924. \$-a határozza meg. Ennek értelmében a fogyasztó követelheti a jogainak gyakorlása során ténylegesen felmerült költségei megtérítését. A jogérvényesítéshez kapcsolódó költségek magukban foglalják a postai küldemény feladásának vagy az áru elszállításának költségeit, valamint a panasz elutasítása után beszerzett szakértői vélemény költségeit is. A költségek megtérítésének jogát az eladóval szemben legkésőbb egy hónappal a 24 hónapos (új termékek esetében) vagy a 12 hónapos határidő (használt termékek esetében) lejárta után kell érvényesíteni.

\subsection{Elévülési határidő}

Minden jog, amelyet a vevő az eladóval szemben érvényesíthet, a jogok keletkezésétől számított három éves határidővel évül el. Az elévülési szabályokat a CsPtk. 628. és 629. \$-ai részletezik.

26 L. Tichý: \$2167. In J. Švestka, J. Dvořák, J. Fiala et al. (eds.): Občanský zákoník, komentářr. Sv. V., Wolters Kluwer, Prague, 2014, 976. 


\section{A jótállás részletes szabályai}

\subsection{A jótállás}

A CsPtk. visszatért az eredeti koncepcióhoz, és elválasztja a teljesítés hibáiból eredő, törvény által garantált jogokat, a minőségi jótállásból származó vevői jogoktól. Amennyiben a felek minőségi jótállásban állapodnak meg, vagy az eladó egyoldalú nyilatkozattal garantálja az áru minőségét, akkor az áru jó minőségéért meghatározott ideig és meghatározott feltételekkel vállal felelősséget A minőség garantálása azonban nem zárhatja ki a szavatossági igényeket, amelyek érvényesítése különösen rejtett hibák esetén lehet fontos. Így tulajdonképpen a jótállást nem a jogszabály biztosítja a vevőnek, hanem arról a feleknek kell megállapodniuk, vagy az eladó biztosíthatja azt egyoldalú nyilatkozatával. Jótállást nemcsak az eladó biztosíthat, hanem bármely harmadik fél, vagy az eladó és egy harmadik fél együttesen. Ekkor a jótállási jogviszony a jótállásra kötelezett és a vevő között jön létre. Ilyen esetben a jótállási nyilatkozat vagy a szerződés konkretizálhatja, hogy ki és hogyan köteles biztosítani a vevőnek a jótállást.

A minőségi jótállást a CsPtk. három helyen szabályozza: a szerződési jog általános részében a CsPtk. 1919. \$-a, az adásvételi szerződésnél a CsPtk. 2113. \$-a és a fogyasztók kal kötött adásvételi szerződésnél a CsPtk. 2165. \$ (2) bekezdése.

A CsPtk. 1919. és 2113. \$-ai értelmében az eladó jótállás keretében vállalja, hogy a dolog egy meghatározott időtartamra alkalmas lesz rendeltetésszerü használatra, és megtartja szokásos tulajdonságait. Ugyanezt eredményezi a szavatossági idő vagy az áru eltarthatóságának a csomagoláson vagy a reklámban való feltüntetése. A CsPtk. 2165. \$-a kiterjeszti a jótállási nyilatkozat listáját az áruk használati utasításaira is.

Ami a jótállás tartalmát illeti a fogyasztóval kötött adásvételi szerződés esetén (CsPtk. 2165. §), a jótállásra vonatkozóan sem találunk olyan rendelkezéseket, amelyek az 1999/44/EK irányelv 6. cikkében megállapított tartalmi feltételeket részleteznék. Mindez a cseh jogszabály és az 1999/44/ EK irányelv 6. cikkének rendelkezései közötti ellentmondáshoz vezet, mivel ez utóbbi előírja azt, hogy a jótállásra kötelezett meghatározza a fogyasztó jótállásból eredő jogait. Kérdéses, hogy a jogalkotó szándékosan tekintett-e el a részletszabályoktól, ezzel korlátozva a fogyasztók jogait, vagy az eladó 
egyébként is köteles részletesen tájékoztatni a fogyasztót a jótállás konkrét tartalmáról. ${ }^{27}$

\subsection{A hibákért való felelősség}

A jótállásból eredő jogok érvényesítése nem érinti a vevőnek a hibás teljesítésből származó törvényes jogait, azaz az eladó hibás teljesítésért való helytállási kötelezettségét. A termék minőségéért történő jótállás egy külön megállapodás, amely a vevő jogait szabályozza, függetlenül attól, hogy a hibák már az átvétel időpontjában fennálltak-e. Ez a szabály akkor is érvényes, ha a CsPtk. ezt külön nem nevesíti.

A jótállási jogok szempontjából a jogtudomány különbséget tesz az önálló és a nem önálló jótállás között. A nem önálló jótállás esetén az eladó jogi felelőssége kibővül, például arra az időszakra, amelyben az eladó felel a teljesített termék minőségéért. Önálló jótállás esetén az eladó jogi felelősségének a kibővüléséről beszélünk a jogi felelősségen túl, például a termék által okozott károkért. ${ }^{28}$

\subsection{A jótállás tartalma és formája}

Az 1999/44/EK irányelv 6. cikkének szövegezése alapján arra lehet következtetni, hogy a jótállás az eladó önkéntes nyilatkozata, az általa eladott áruk szerződésszerű minőségére vonatkozóan tett vállalás. Az eladónak azonban nem feltétlenül kell kifejezett ,jótállási nyilatkozatot” tennie, a CsPtk. 2165. \$ (2) bekezdése értelmében elegendő az áru csomagolásán feltüntetett vagy egyéb módon tett minőségi utalás. Így alapvetően az eladó határozza meg a jótállást és annak tartalmát, így különösen a vevők jogait és a hibás teljesítésért való felelősségen túlnyúló minőségi garancia mértékét.

A fentiekre tekintettel megkérdőjelezhető, hogy a jótállásvállalás az eladó egyoldalú kötelező erejű ígérete-e, amelyet a vevőnek nem kell kifejezetten elfogadnia, vagy pedig minden esetben jótállási szerződést kell-e kötniük a feleknek? A kérdés kezelése a nemzeti jogalkotóra van bízva, de sajnos a cseh jogalkotó nem foglalkozott ezzel a kérdéssel. Úgy gondoljuk, hogy mivel a CsPtk. szerint a kötelezettségek keletkezhetnek egyoldalú nyilatkozattétellel is (CsPtk. 1723. \$), az eladó egyoldalú nyilatkozatát kötelező érvényű akaratnyilatkozatnak

27 L. Tichý: \$2165. i. m., 972.

28 L. Tichý: $\$ 2113$. In J. Švestka, J. Dvořák, J. Fiala et al. (eds.): Občanský zákoník, komentárr.Sv.V., Wolters Kluwer, Prague, 2014, 944. 
kell tekinteni, amelynek következményei függetlenek attól, hogy a vevő kifejezetten elfogadta-e a nyilatkozatot.

A jótállás tartalmát illetően a CsPtk. nem tartalmaz részletes szabályokat. A jótállási nyilatkozat formai követelményeire nézve sem találunk speciális rendelkezést az fogyasztókkal kötött adásvételi szerződéseknél, ezért szóbeli nyilatkozat is lehetséges. A gyakorlatban azonban a jótállási nyilatkozatot gyakran írott formában is csatolja az eladó (aláírásával azonban nem látja el), hogy az elegendő bizonyítékot szolgáltasson a fogyasztónak a szavatosság tartalmáról. A fogyasztónak arra is van joga, hogy írásban kérje az eladótól a jótállási nyilatkozatot, továbbá faxon, e-mailben vagy más olyan módon, hogy rendelkezésére álljon. A CsFvt. 11.\$-a értelmében minden információt cseh nyelven kell megadni, amennyiben az írott formájú.

A jótállási nyilatkozatot az áruk eladásakor közli az eladó a vevővel, amikor kifejezi szándékát a jótállás vállalásáról. A jótállási nyilatkozat akkor is érvényes, ha annak szövege vagy a tartalma nem felel meg az 1999/44/EK irányelvben elöírt összes követelménynek. Az eladó akarata irányadó.

\subsection{A jótállás feltételei}

A jótállás vonatkozhat az adásvételi szerződés tárgyára vagy a termék egyetlen, meghatározott részére. Hasonlóképpen, a minőségi garancia csak egy bizonyos tulajdonságra vagy funkcióra is vonatkozhat, és különféle jótállási feltételeket lehet megállapítani a jótállással biztosított tulajdonságokra, így különös tekintettel a vásárló jogaira és a jótállás időtartamára. ${ }^{29}$

Mivel a jótállási nyilatkozatot többféle formában is lehet tenni, a CsPtk. 2114. \$-a azt a kérdést is rendezi, hogy mi történik, ha ugyanazon árura különféle jótállási határidőket állapított meg az eladó.

- Általános szabályként az érvényesül, hogy ha a szerződés és a jótállási nyilatkozatok eltérő jótállási határidőket állapítanak meg, akkor a leghosszabb időtartamot kell érvényesnek tekinteni. A jótállási nyilatkozatot e rendelkezés értelmében úgy kell tekinteni, mint az eladó egyoldalú akaratnyilatkozatát, akkor is, ha az a csomagoláson, a reklámban vagy a termékleírásban szerepel.

29 J. Zapletal: \$2116. In: J. Petrov, M. Výtisk, V. Beran et al. (eds.): Občanskýzákonik, komentáŕ. C.H.BECK, Prague, 2017, 2143. 
- A második szabály értelmében, ha a felek olyan jótállási időpontban állapodnak meg, amely eltér a csomagoláson feltüntetett használati időponttól, akkor a felek megállapodása az irányadó.

\subsection{A jótállási határidő}

A jótállás határideje áru átvételétől kezdődik. Lehetnek azonban kivételek:

- Ha az árut a szerződés szerint leszállítják a vevőnek, akkor a jótállási idő abban a pillanatban kezdődik, amikor az áru megérkezik a rendeltetési helyére.

- Ha a vásárolt dolgot az eladótól különböző személy helyezi üzembe, akkor a jótállási idő a termék üzembe helyezésének napján kezdődik. Ez a feltétel azonban csak akkor érvényes, ha a vevő legkésőbb a termék kézhezvétele után három héten belül kéri az üzembe helyezést, és megfelelő együttműködést tanúsít ahhoz, hogy az üzembe helyező időben teljesíthessen.

A jótállás határideje nyugszik azon időtartam alatt, amely alatt a vevő nem tudta használni a hibás terméket, a hibás teljesítésből eredő jogainak érvényesítése miatt.

\subsection{A jótállásból eredő jogok kizárása}

A CsPtk. 2116. \$-a meghatározza azt az esetet, amikor a vevőt nem illeti meg a jótállás. Az egyértelmü esetek mellett, amikor a vevő maga okozza a kárt az áruban, akkor lehet szó erről, amikor a kárviselés kockázatának átszállását követően egy külső esemény, például vis maior vagy harmadik fél cselekedetei okozzák a hibát. Ha azonban a hiba felmerülését az eladó magatartása idézte elő, akkor az eladó felel a felmerült hibákért. ${ }^{30}$

30 J. Zapletal: $\$ 2116$. i. m., 2143. 


\subsection{A jótállással kapcsolatos speciális kérdések a fogyasztókkal kötött adásvételi szerződéseknél}

Két alapvetően eltérő vélemény létezik a cseh joggyakorlatban a jótállási jog terjedelmével kapcsolatban a fogyasztóval kötött adásvételi szerződéseknél. Míg e fejezet szerzője azt a véleményt osztja, hogy a fogyasztókkal kötött adásvételi szerződésnél érvényesülő jótállási jog kizárólag a már említett CsPtk. 2165. $\$$. (2) bekezdéséből származtatható, egy másik nézet szerint a jótállás szintén a CsPtk. 2165. \$ (1) bekezdéséből fakad. Ez azonban nem szerződéses jótállás lenne, hanem úgynevezett törvényes jótállás, amint azt a korábbi CsPtk. is tartalmazta. ${ }^{31}$

A két megközelítés közötti fö különbség abban rejlik, hogy kit terhel a hiba fennállásának bizonyítási terhe olyan rejtett hibák esetén, amelyeket hat hónappal az átvétel után jelentkeznek, azaz akkor, amikor a hiba átvételkori megléte már nem vélelmezhető. A mi nézetünk szerint ebben az esetben a vevőnek kell bizonyítania, hogy a hiba már az áru átvételének időpontjában létezett. A törvényes jótállás esetén az eladónak kell bizonyítania, hogy a termék nem volt hibás.

Az alapvető eltérés azon 24 hónapos időszak értelmezésénalapul, amelyen belül a hibát be kell jelenteni. A negatív nézet hívei azt feltételezik, hogy a 24 hónapos határidő nem szab határidőt a hiba közlésére az eladóval, hanem azt az időszakot jelöli, amely alatt az a hiba keletkezik, amelyért az eladó felelős.

A témáról folytatott vita remélhetőleg okafogyottá válik a CsPtk. aktuális módosítása után, mivel az aktuális tervezet szerint a CsPtk. 2161. és 2165. \$-át is módosítani fogja a jogalkotó. A norma javasolt új szövege kifejezetten kimondja, hogy az eladó felel azért, hogy az áru az átvételkor hibátlan volt (2161. §). „A vevő a hibát az áru kézhezvételétől számított két éven belül érvényesítheti; ami nem érinti a CsPK 2161a. \$-át. A bíróság a hiba érvényesítésének jogát akkor is biztosítja, ha a hibát nem érvényesítették indokolatlan késedelem nélkül azután, hogy a vevő kellő gondossággal észlelte a hibát."

31 P. Hubková: $\$ 2165$. i. m., 2189.; F. Melzer: K úpravě ochrany spotřebitele ve vládním návrhu občanského zákoníku. Právní rozhledy, Vol. 17. 2009/21. 771-776.; B. Vítová: \$2165. i. m., 157.; T. Liškitín: Otazníky nad zákonnou zárukou při prodeji zboží v obchodě od ledna 2014. Právní rozhledy, Vol. 22. 2014/5. 160-164. Ezt a véleményt az Igazságügyi Minisztérium és a Kereskedelmi és Ipari Minisztérium közös nyilatkozata is megerösítette, elérhetö: http://obcanskyzakonik.justice.cz/index.php/home/infocentrum/infocentrum-aktuality/214dvouleta-zakonna-zaruka-na-zbozi-bude-platit-i-po-1-1-2014 (letöltés dátuma: 2020.02.10.) 


\section{A fogyasztó egyéb jogai a szerződés hibás teljesítéséhez kapcsolódóan}

Ha az eladó a szerződés hibás teljesítésével kárt okoz, a kártérítési igényre jogosult lesz a károsult. A kár ebben az esetben az a kár, amely a hibás teljesítés eredményeként keletkezett a szerződés tárgyát képező termékben vagy egy másik termékben.

A kétféle kártérítés a CsPtk. 1925. §-án alapul, amely szerint a hibás teljesítésből eredő szavatossági jog nem zárja ki a kártérítéshez való jogot; azonban amit a hibás teljesítésért való helytállás keretében vissza lehet téríttetni, arra nem keletkezhet további kártérítési igény, tehát a „kétszeres-kártérítés” lehetősége kizárt.

Ebből a rendelkezésből az következik, hogy a hibákért és a károkért való felelősség két különféle jogi kötelezettség, melyeknek eltérő célja van és a felelősség más-más elvei érvényesülnek. A hibákért való felelősség esetén az eladó saját teljesítésének hiányosságaiért felel és azt biztosítja, hogy a vevő hiánytalan teljesítésben részesül, azaz a megvásárolt termék rendelkezik azokkal a tulajdonságokkal, amiben megállapodtak a felek és hibátlan. A kártérítési felelősség célja viszont az, hogy kompenzálja azokat a vagyoni károkat, amelyek a jogi kötelezettség megszegése miatt vagy más jogilag elismert tény következtében keletkeznek. ${ }^{32}$

A hibás teljesítéssel okozott kár esetén a károkért való felelősséget a szerződéses kötelezettség megszegésére vonatkozó CsPtk. 2913. \$ határozza meg. A szerződéses felelősségre mind a CsPtk. általános részeit, mind a speciális, konkrét szerződésre vonatkozó szabályait alkalmazni kell. Az általános rendelkezés értelmében, ha valamely szerződéses fél szerződésszegése kárt okoz, akkor a károkozó minden esetben köteles megtéríteni a kárt, és a jogsértésért felelős személy csak akkor mentesülhet a felelősség alól, ha bizonyítja, hogy rendkívüli, előre nem látható esemény okozta a kárt. ${ }^{33}$

A vevő a CsPtk. 2936. \$-a alapján is folyamodhat kártérítésért, ha valamely kötelezettség teljesítésekor használt tárgy (például szerszám, gépek stb.) okozott kárt, vagy a CsPtk. 2939. \$-a alapján, ha a hibás termék okozta a kárt. Az ilyen típusú felelősségvállalás (strict liability) a veszélyes üzemi felelősség esetének

32 A Legfelsőbb Bíróság 25 Cdo 1612/2004. számú határozata.

33 J. Hrádek, A. Bell: The New Civil Code and Compensation for Damage: Introductory Remarks. JETL, Vol. 7. 2016/3. 303. 
minősül, és a jogsértő szándékosságától függetlenül fennáll a kártérítési kötelezettség. Noha az első eset nem teszi lehetővé a jogsértő mentesítését felelősség alól, a hibás termék által okozott károkért való felelősség lehetővé teszi a kimentést a 85/374/EK irányelvben meghatározott esetekben.

\section{A hibás teljesítésből eredő jogok érvényesítésének szabályai}

Az a kérdés, hogy milyen eljárás keretében érvényesítheti a fogyasztó kárigényeit, alapvetően attól függ, hogy a törvényi szavatosságból vagy jótállásból erednek-e az igényei. Míg a CsFvt. 19. \$-a meghatározza az eladó alapvető kötelezettségeit a hibás teljesítésért való törvényes szavatosság esetére, addig az eladó konkrét kötelezettségei jótállás esetén eltérőek lehetnek a jótállási megállapodásnak, illetve a nyilatkozatnak megfelelően. A vállalt kötelezettségek ezutóbbi esetben a fogyasztónak küldött jótállási nyilatkozatban találhatók meg, amit az eladó írott formában juttat el a vevőnek.

\subsection{A panasz benyújtásának helye}

A követelés érvényesítésének helyére vonatkozó alapvető rendelkezések értelmében (CsPtk. 2172. \$) a hibás teljesítésből eredő jogokat az eladóval szemben kell érvényesíteni, akitől a terméket vásárolták. Kivéve, ha a vásárlásról szóló igazolásban más, javításra kijelölt személyben egyeztek meg a felek (CsPtk. 2166. \$), aki például könnyebben elérhető a vevő számára. A javításra kijelölt személy a javítást az eladó és a vevő által az adásvételkor megállapított határidőn belül végzi el.

Azon esetek kivételével, amikor egy másik személyt jelölnek ki a javítás elvégzésére, az eladó köteles a panaszt minden olyan helyen elfogadni, ahol érvényesíteni lehet a panaszt (székhely, üzlethelység, telephely stb.). Az eladó köteles írásban visszaigazolni a fogyasztónak a panasz felvételét, annak tartalmát és a fogyasztó által igényelt panaszkezelési módot. A folyamat végén az eladó visszaigazolja a felmondás határidejét, a panasz kezelés módját, beleértve a javítás végrehajtását és annak időtartamát vagy írásban indokolja a panasz elutasításának okait. Ez a kötelezettség a javítás elvégzésére kijelölt más személyekre is vonatkozik. 


\subsection{A panasz tartalma}

A vevő panaszának tartalmaznia kell a hiba bejelentését, annak konkrét leírását, valamint a panasz kezelésére választott módszert. Ezenkívül a vevőnek azt is igazolnia kell, hogy valóban ő vásárolta a hibás terméket. Ha a vevő nem rendelkezik az adásvételt igazoló okmánnyal, más hiteles módon kell bizonyítania a vásárlás megtörténtét, pl. számlával, vagy az eladó által kiadott visszaigazolással. ${ }^{34}$

\subsection{Eljárási szempontok}

A hibás terméket az eladó vagy a szolgáltató rendelkezésére kell bocsájtani, hogy felmérhesse és kijavíthassa a hibát, kivéve, ha más eljárásban állapodtak meg a felek. Ez lehet például egy javító szervíz kiszállásának közbeiktatása a vevőnél vagy a hiba távoli kijavítása. Ha a vevőnek költségei merülnek fel a panasz benyújtásával, akkor joga van arra, hogy azt megtéríttesse az eladóval, mivel ezek a költségek közvetlenül kapcsolódnak a hiba felmerüléséhez.

Az eladó köteles elfogadni a panaszt és nem utasíthatja el azt még akkor sem, ha indokolatlannak ítéli meg. A panasz benyújtásakor a fogyasztónak nem kell az eladóhoz szállítania azokat a terméktartozékokat, amelyekhez nem kapcsolódik a hiba, így például a vevőnek nem kell elküldenie a telefonját, ha a követelés csupán a telefontöltőre vonatkozik. Ha azonban az eladó ennek ellenére követelné ezeket, azzal megsérti a CsFvt. 13. és 19 . \$-ait. ${ }^{35} \mathrm{Az}$ eladó akkor sem utasíthatja el a panaszt, ha az áruk piszkosak vagy a kopás jeleit mutatják. ${ }^{36}$

\subsection{Az eljárás időtartama és kimenetele}

A CsFvt. elöírja, hogy a panaszokat - beleértve a hibátlan teljesítés helyreállítását is - indokolatlan késedelem nélkül kell rendezni, de figyelembe kell venni a termék és szolgáltatás fajtáját, amelyek befolyásolják a hiba szakmai megítélését.

34 Lásd B. Vítová: \$2165. i. m., 158.

35 B. Vítová: $\$ 2173$. In: M. Hulmák et al. (eds.): Občanský zákoník VI. Závazkové právo. Zvláštní cást (S 2055-3014). C.H.Beck, Prague, 2014, 174.; lásd az Alkotmánybíróság IV. ÚS 512/05. és III. ÚS 2983/08. ügyszámú eseteit.

36 A Cseh Kereskedelmi Felügyelet weboldala, elérhető:https://www.coi.cz/pro-spotrebitele/spotrebitelskypruvodcel (letöltés dátuma: 2020.02.15.). 
Legkésőbb azonban a panasz benyújtásától számított 30 napon belül teljesíteni kell a fogyasztó igényét, kivéve, ha az eladó és a fogyasztó ennél hosszabb időtartamban állapodnak meg. A határidő módosításáról kifejezetten meg kell állapodni a fogyasztóval, egy egyoldalúan előre meghatározott, nyomtatott formális megállapodás nem fogadható el.

Ennek az időszaknak a hiábavaló lejártát lényeges szerződésszegésnek kell tekinteni és a vevő elállhat a szerződéstől. A panaszos eljárása csak akkor eredményes, ha az eladó felméri a hibát, és ha az értékelés a fogyasztó javát szolgálja, majd az eladó eltávolítja a hibát és a vevőt tájékoztatja a panasz eredményéről. ${ }^{37}$ Ha az eladó elutasítja a panaszt, akkor az árun más módosítást nem végezhet a fogyasztó hozzájárulása nélkül. Hasonlóképpen, nem lehet elutasítani a hibát egy másik olyan hiba előfordulása miatt, amelynek nincs kimutatható hatása az állítólagos tényre. Az eladó mindig csak azt a konkrét hibát tudja kezelni, amelyet kifogásolt a fogyasztó. ${ }^{38}$

\subsection{A felmerült költségek megtérítése}

Ami a jogok érvényesítésével kapcsolatos költségeket illeti, a fogyasztó jogosult a joggyakorlás során felmerült tényleges költségeinek megtérítésére. A panaszhoz kapcsolódó tipikus költségek magukban foglalják a postai küldemények, az áru szállításának költségeit, valamint a panasz elutasítása után igényelt szakértői vélemény költségeit. Az eladónak joga van megvizsgálni a felmerült költségek célszerűségét, és például nem megfelelő szállítás esetén leszállítani a költségigényt.

Ami a költségtérítés terjedelmét illeti, a törvény nemcsak azokra az esetekre vonatkozik, amikor az eladó megalapozottnak ítéli a fogyasztó igényeit, hanem általában minden olyan esetre, amikor a fogyasztó által kifogásolt termék hibás. Nem egyértelmű, hogy mindez azokra az esetekre is vonatkozik-e, amikor a fogyasztó visszaél a jogaival, vagy nem megalapozott a panasza. ${ }^{39}$ A szakirodalom szerint, ha a vevő tudatában van (vagyis tudnia kellett volna), hogy az eladó nem felelős a hibáért (például a vevő maga okozta a hibát), és ennek

37 B. Vítová: $\$ 2172$. In: M. Hulmák et al. (eds.): Občanský zákoník VI. Závazkové právo. Zvlástní část (S 2055-3014). C.H.Beck, Prague, 2014, 172.

38 A Cseh Kereskedelmi Felügyelet weboldala, i. $m$.

39 A Legfelsőbb Közigazgatási Bíróság 3 As 60/2005. számú határozata szerint az eladó által meghatározott jótállási feltételek minden olyan rendelkezése, amely felhívja a fogyasztó figyelmét az indokolatlan panaszok költségeire, „korlátozó hatással van a fogyasztók azon jogaira, hogy a hibás teljesítésből eredő igényeiket érvényesítsék". 
ellenére érvényesíti a hibás teljesítésből származó jogokat, akkor ezek a költségek nem terhelik az eladót. Ilyen eset nem tekinthető a fogyasztó jogérvényesítéshez való joga korlátozásának. Bizonyos esetekben mérlegelni kell, hogy amennyiben az eladó a panasz áldozattá válik, akkor alkalmazni lehet a CsPtk. 2909. \$-át, azaz a jó erkölcs megsértésével okozott károkért való felelősség szabályait. ${ }^{40}$ A költségtérítés igényét az eladóval szemben legkésőbb a 24 hónapos vagy más szavatossági időszak lejártát követő egy hónapon belül kell érvényesíteni (CsPtk. 1924. \$).

\subsection{További jogi lépések}

Ha az eladó nem tesz eleget a fogyasztó kifogásának, akkor a fogyasztó kereset nyújthat be a bírósághoz az 1963. évi 99. számú, Polgári perrendtartásról szóló törvény ${ }^{41}$ alapján vagy alternatív vitarendezési eljárást vehet igénybe. Mindezek mellett a vevő panaszt nyújthat be a Cseh Kereskedelmi Felügyelethez, amely eljárást indít és a jogszabályban megkövetelt megalapozottság esetén bírságot szab ki.

A békéltető eljárás lefolytatásának szabályait a CsFvt. részletezi, melynek keretében a fogyasztók a CsFvt. 20d. \$-a szerint kezdeményezhetik az alternatív vitarendezési eljárást, ha a panaszt nem lehetett közvetlenül rendezni az eladóval.

Ami a polgári bírósági eljárást illeti, a fogyasztók egyéni jogorvoslatot is kezdeményezhetnek a bíróság előtt annak érdekében, hogy az eladó hibás teljesítéséből eredő jogaikat érvényesíteni tudják. Az ilyen eljárás azonban meglehetősen hosszú, költséges és kiszámíthatatlan eredménnyel jár, továbbá a fogyasztót terhel mindennemü bizonyítási teher. Ezenkívül a fogyasztónak eljárási illetékeket is kell fizetnie, amelyek pénzbeli összege az igényelt összeg 4 vagy $5 \%$-át teszi ki, a kereset típusától függően, ezért kisebb összegű kárigénynél nagyon ritka a bírósági eljárás.

40 P. Bezouška: Neoprávněná reklamace. Právní rádce. 2006/12. 15.

41 1963. évi 99. számú törvény a polgári eljárásról (Zákon č. 99/1963 Sb., občanský soudní rád). 


\section{Forrásjegyzék}

I. P. Bezouška: Neoprávněná reklamace. Právní rádce. 2006/12. 15-17.

2. J. Hrádek: Damage caused by Product Defects and (Legitimate) Expectation Concerning Product Safety. In: V.L. Petrov, V. Tokušev (eds.): Sbornik naučni izsledovanie $v$ pamet na doc. Christian Takov. Universitetsko izdatelstvo „Sv. Kliment Ochridski“, Sofia, 2019, 312-324.

3. J. Hrádek, A. Bell: The New Civil Code and Compensation for Damage: Introductory Remarks. JETL, Vol. 7. 2016/3. 300-307.

4. M. Hulmák: Prostředky právní ochrany kupujícího při spotřebitelské koupi. In: L. Tichý, M. Kocí (eds.): Spotrebitelská kupní smlouva. Centrum právní komparatistiky, Praha, 2013. 27-43.

5. T. LišKitín: Otazníky nad zákonnou zárukou při prodeji zboží v obchodě od ledna 2014. Právni rozhledy, Vol. 22. 2014/5. 160-165.

6. F. Melzer: K úpravě ochrany spotřebitele ve vládním návrhu občanského zákoníku. Právni rozhledy, Vol. 17. 2009/21. 771-776.

7. J. Petrov, M. Výtisk, V. Beran et al. (eds.): Občanský zákoník, komentár. C.H.BECK, Prague, 2017.

8. J. Švestika, J. Dvořák, J. Fiala et al. (eds.): Občanský zákoník, komentár Sv.V., Wolters Kluwer, Prague, 2014.

9. A Tanács irányelve (1985. július 25.) a hibás termékekért való felelősségre vonatkozó tagállami törvényi, rendeleti és közigazgatási rendelkezések közelítéséről, HL L 210., 1985.8.7., 29-33.

10. Az Európai Parlament és a Tanács 1999/44/EK irányelve (1999. május 25.) a fogyasztási cikkek adásvételének és a kapcsolódó jótállásnak egyes vonatkozásairól, HL L 171., 1999.7.7., 12-16.

11. Az Európai Parlament és a Tanács (EU) 2019/770 irányelve (2019. május 20.) a digitális tartalom szolgáltatására és digitális szolgáltatások nyújtására irányuló szerződések egyes vonatkozásairól, HL L 136., 2019.5.22., 1-27.

12. Az Európai Parlament és a Tanács (EU) 2019/771 irányelve (2019. május 20.) azáruk adásvételére irányuló szerződések egyes vonatkozásairól, az (EU) 2017/2394 rendelet és a 2009/22/EK irányelv módosításáról, valamint az 1999/44/EK irányelv hatályon kívül helyezéséről, HL L 136., 2019.5.22., 28-50. 
FogYASZTÓI ADÁSVÉTEL EGYES KÉRDÉSEI - CSEHORSZÁG

13. 1963. évi 99. számú törvény a polgári eljárásról (Zákon č. 99/1963 Sb., občanský soudni rád)

14. 1992. évi 634. számú törvény a fogyasztóvédelemről (Zákon č. 634/1992 Sb., o ochraně spotřebitele)

15. 2012. évi 89. számú Polgári törvénykönyv (Zákon č. $89 / 2012$ Sb., občanský zákoník).

16. A CsPtk. módosításának tervezete,1170/19. sz., elérhető: https:/lapps.odok. cz/veklep-detail:pid=KORNBFQGCDCT (letöltés dátuma: 2020.02.10.)

17. Európai Unió Bíróságának C-269/95. sz. Benincasa kontra Dentalkit ügyben 1997. július 3-án hozott ítélete (ECLI:EU:C:1997:337)

18. Európai Unió Bíróságának C-497/13. sz. Froukje Faber kontra Autobedrijf Hazet Ochten BV ügyben 2015. június 4-én hozott ítélete (ECLI:EU:C:2015:357)

19. Alkotmánybíróság IV. ÚS 512/05. ügyszámú határozata

20. Alkotmánybíróság III. ÚS 2983/08. ügyszámú határozata

21. Legfelsőbb Bíróság 25 Cdo 1612/2004. számú határozata

22. Legfelsőbb Bíróság 33 Odo 1314/2005. számú határozata

23. Legfelsőbb Bíróság 30 Cdo 68/2007. számú határozata

24. Legfelsőbb Bíróság 33 Cdo 1323/2013. számú határozata

25. Legfelsőbb Bíróság 33 Cdo 2889/2015. számú határozata

26. Legfelsőbb Közigazgatási Bíróság 3 As 60/2005. számú határozata

27. Az Igazságügyi Minisztérium és a Kereskedelmi és Ipari Minisztérium közös nyilatkozata, elérhető: http://obcanskyzakonik.justice.cz/index.php/ homelinfocentrum/infocentrum-aktuality/214-dvouleta-zakonna-zarukana-zbozi-bude-platit-i-po-1-1-2014 (letöltés dátuma: 2020.02.10.)

28. A Cseh Kereskedelmi Felügyelet weboldala, elérhető: https://www.coi.cz/prospotrebitele/spotrebitelsky-pruvodcel (letöltés dátuma: 2020.02.15.). 
Dr. Jiří HrádeK PhD., a prágai Károly Egyetem (Univerzita Karlova) Jogi Karának Összehasonlító Jogi Központjának kutatója és a Zeppelin CZ s.r.o társaság ügyvédje. Jogi diplomáját a Károly Egyetem Jogi Karán szerezte 2002ben. Tanulmányokat folytatott a Hamburgi Egyetemen (2000-2001 között), LLM képzésben vett részt a Tubingeni Eberhard-Karls Egyetemen (2002-2003 között) és a Károly Egyetem posztgraduális képzését is elvégezte (2002-2009 között). 2002-ben és 2003-ban a bécsi Európai Kártérítési és Biztosítási Jogi Központ kutatásában vett részt (ECTIL); 2007-ben az Európai Bizottság ösztöndíjasa volt, az Egészségügyi és Fogyasztóvédelmi Főigazgatóságnál. Jiří Hrádek a cseh Jurisprudence (Jogtudomány) folyóirat szerkesztőbizottságának tagja. Szakterülete a polgári jog és a polgári eljárásjog, különös tekintettel a szerződésen kívüli kártérítési jogra. A szerződéskötés előtt okozott károkért való felelősségről szóló szakkönyv szerzője, továbbá szerződésen kívüli kártérítéssel kapcsolatos szakkönyv, valamint a cseh polgári törvénykönyvről és a cseh polgári perrendtartásról szóló kommentárok társszerzője. Ezen túl rendszeresen publikál hazai és külföldi szakmai folyóiratokban. 